\section{Evaluating Fertility of Triploid Clones of Hypericum androsaemum L. for Use as Non-invasive Landscape Plants}

\author{
Clara E. Trueblood ${ }^{1}$, Thomas G. Ranney ${ }^{2,5}$, and Nathan P. Lynch $^{3}$ \\ Department of Horticultural Science, Mountain Horticultural Crops \\ Research and Extension Center, North Carolina State University, 455 \\ Research Drive, Mills River, NC 28759 \\ Joseph C. Neal' \\ Department of Horticultural Science, North Carolina State University, \\ Raleigh, NC 27695
}

Richard T. Olsen ${ }^{4}$

USDA-ARS Floral and Nursery Plants Research Unit, U.S. National Arboretum, 3501 New York Avenue NE, Washington, DC 20002

Additional index words. tutsan, St. John's wort, invasive plants, ornamental plant breeding, reproductive biology

\begin{abstract}
Although Hypericum androsaemum $\mathrm{L}$. is a valuable landscape plant, the species can be weedy and potentially invasive in certain locations. Infertile, non-invasive cultivars of $\boldsymbol{H}$. androsaemum with desirable ornamental features would be ecologically beneficial and valuable for the horticultural industry. The male and female fertility of 10 triploid $H$. androsaemum, developed with a combination of variegation and foliage colors, was investigated under greenhouse (controlled pollination) and field conditions (natural pollination). Male fertility was evaluated based on pollen viability tests (pollen staining and pollen germination). Female fertility was based on fruit set, seed set, germinative capacity of seeds, and number of seedlings produced for each flower. Although values for different measures of fertility varied among triploid clones, pollen germination was significantly reduced for all triploids and nine of the 10 triploids produced no viable seed. These results represent $100 \%$ failure of $\approx 171,000$ potential fertilization events based on fertility levels of diploid controls. The remaining triploid clone produced two seedlings per flower compared with 260 seedlings per flower for the controls. However, the seedlings produced by the triploid clone died shortly after germination. This research documented that the triploid $\boldsymbol{H}$. androsaemum tested are highly infertile with no measurable female fertility. These clones will provide ideal alternatives to fertile forms of $\boldsymbol{H}$. androsaemum where invasiveness is a concern. These methods also provide a useful protocol for evaluating fertility of other taxa that are selected or developed as non-invasive cultivars of potentially weedy species.
\end{abstract}

The genus Hypericum L. (Hypericaceae Jussieu) contains $\approx 400$ species of small trees, shrubs, and herbs, including many ornamental plants that are grown for their attractive,

Received for publication 24 Mar. 2010. Accepted for publication 2 June 2010 .

This research was funded, in part, by the North Carolina Agricultural Research Service (NCARS), Raleigh, NC, and the U.S. Department of Agriculture Agricultural Research Service, Floriculture and Nursery Research Initiative, Beltsville, MD.

Support and guidance from Frank A. Blazich, Professor, North Carolina State University, along with technical assistance of Thomas Eaker, Joel Mowrey, Jeff Jones, and staff of the Mountain Horticultural Crops Research and Extension Center is greatly appreciated.

${ }^{1}$ Graduate Research Assistant

${ }^{2}$ Professor of Horticultural Science.

${ }^{3}$ Research Specialist.

${ }^{4}$ Research Geneticist.

${ }^{5}$ To whom reprint requests should be addressed; e-mail tom_ranney@ncsu.edu. including 7, 8, 9, 10, and 12 over a range of ploidy levels (Matzk et al., 2003; Robson and Adams, 1968). Hypericum androsaemum has been reported to be $2 n=40$, suggesting this species is tetraploid compared with taxa in other sections with $2 n=20$ (Robson and Adams, 1968). However, inheritance studies conducted by Olsen et al. (2006) demonstrated that segregation patterns for foliage traits in $H$. androsaemum fit a diploid model. These results suggest that $H$. androsaemum may be an allopolyploid (amphidiploid) or an autotetraploid that has undergone diploidization. As such, $H$. androsaemum was treated as a diploid with $2 n=2 x=40$.

Olsen et al. (2006) studied the potential for breeding non-invasive, infertile triploid cultivars of $H$. androsaemum with variegated and purple ornamental foliage types. Five randomly selected triploid plants were found to be highly infertile as demonstrated by low pollen germination (less than 6\%) and no measurable fruit or seed set after controlled pollination. The further development of improved, non-invasive cultivars of $H$. androsaemum is desirable for landscape applications; however, it is necessary to evaluate and document infertility of each desirable clone to ensure their non-invasiveness.

The objectives of this study were to confirm the ploidy levels and evaluate male and female fertility under natural and controlled pollination conditions of individual, triploid clones of $H$. androsaemum before commercial release.

\section{Materials and Methods}

Experiments were conducted at the Mountain Horticultural Crops Research Station (MHCRS) in Mills River, NC, using plant material developed through previous breeding efforts (Olsen et al., 2006). Ten triploid ( $2 n=$ $3 x=60)$ taxa, including four selections with purple foliage (H2006-018-003, H2006-018011, H2006-018-012, and H2006-069), three selections with variegated foliage (H2006018-005, H2006-019-005, H2006-019-006), and three selections with a combination of both variegated and purple foliage (H2006018-004, H2006-018-006, H2006-018-010), were evaluated. Additional plants of diploid $H$. androsaemum seedlings served as controls and sources of pollen. Plants were grown at MHCRS in 18.9-L containers with a pine bark substrate amended with $2.8 \mathrm{~kg} \cdot \mathrm{m}^{-3}$ dolomitic limestone, $0.5 \mathrm{~kg} \cdot \mathrm{m}^{-3}$ micronutrients (Micromax; The Scotts Co., Marysville, $\mathrm{OH}$ ), and $50 \mathrm{~g}$ per container of $15 \mathrm{~N}-3.9 \mathrm{P}-10.0 \mathrm{~K}$ controlled-release fertilizer (15-9-12 Osmocote Plus; The Scotts Co.) and were watered as needed by hand or with drip irrigation.

Fertility studies were conducted in two locations: 1) in a plastic-covered greenhouse where hand pollination was completed using a mixture of fresh pollen collected daily from five diploid seedlings; and 2) an outdoor field study using container-grown plants, spaced $1 \mathrm{~m}$ apart, on a gravel container nursery pad in full sun with natural pollination. Each experiment (greenhouse and field) was a completely 
randomized design with 11 taxa and five single-plant replicates per taxa.

Holoploid 2C DNA content (i.e., DNA content of the entire nonreplicated, chromosome complement) was determined through flow cytometry (Doležel et al., 1998) for all of the plants included in this study. Nuclei isolation and staining (4', 6-diamidino-2phenylindole) followed the protocols provided by Palmer et al. (2009). The mean fluorescence of each sample was compared with an internal standard of known genome size: Pisum sativum L. 'Ctirad', $2 \mathrm{C}=8.76 \mathrm{pg}$ (Greihuber et al., 2007).

Evaluating male fertility. Fresh pollen was collected from flowers at anthesis for each plant and used for viability tests. Pollen grains were stained in $40 \mu \mathrm{L}$ of $1 \%$ acetocarmine on a microscope slide. The slide was heated three times over a hot plate set at medium-low temperature to heat without boiling for $5 \mathrm{~s}$, sealed with valap (1 petroleum jelly: 1 lanolin:1 paraffin by weight), and incubated at room temperature $\left(23^{\circ} \mathrm{C}\right)$ for $5 \mathrm{~h}$. Stained, well-formed pollen grains were scored as viable. Pollen germination was observed in $5-\mathrm{mL}$ petri dishes containing Brewbaker and Kwack (1963) media supplemented with 5\% sucrose and solidified with $2 \%$ agarose (Marquard, 1992). Pollen grains with pollen tubes greater than one-half the diameter of the pollen grain after $5 \mathrm{~h}$ were scored as germinated. Pollen staining and germination were observed using a compound light microscope (Nikon Eclipse 80i, Tokyo, Japan) under $\times 100$ and $\times 400$ magnifications. For each replicate, 100 or more pollen grains were scored.

Evaluating female fertility (greenhouse study). Ten flowers from each single plant replicate of all 11 taxa were hand-pollinated daily for as long as they were receptive using a mixture of fresh pollen collected daily from five diploids plants. Flowers were not emasculated. The experimental design was completely randomized with five replications $(\mathrm{n}=5)$ and 10 flowers (subsamples) per single plant replicate. Fruit were harvested when capsules matured and turned from bright red to brown. Percentage of fruit set (percentage of tagged/pollinated flowers that formed fruit), number of seeds per fruit, and germinative capacity of seeds were determined. Germinative capacity of seeds harvested from successful crosses was determined using in vitro germination. Two germination blotters (SDB3.5; Anchor Paper Co., St. Paul, MN), soaked with $100 \mu \mathrm{M}$ gibberellic acid $\left(21 \mathrm{~g} \cdot \mathrm{L}^{-1}\right.$ Provide ${ }^{\circledR}$; Valent Biosciences, Walnut Creek, CA), were placed in $10-\mathrm{cm}$ petri dishes. A sample of 50 seed per fruit, or all seed available when less than 50 , was sown per petri dish. Petri dishes were sealed with parafilm and placed in a growth chamber maintained at $24{ }^{\circ} \mathrm{C}, 16-\mathrm{h}$ light/8-h dark period, and $42 \mu \mathrm{mol} \cdot \mathrm{s}^{-1} \cdot \mathrm{m}^{-2}$ photosynthetically active radiation provided by fluorescent lights. After 8 weeks, seeds with emerged radicles were scored as germinated. Average number of seedlings produced from each flower was calculated for each plant as: ( $\%$ fruit set $/ 100)$ $\times$ seeds per fruit $\times(\%$ germination $/ 100)$.
Evaluating female fertility (field study). Twenty-five flowers on each single plant replicate per taxon were selected and allowed to undergo natural pollination. The experimental design was completely randomized with five replications $(n=5)$ and 25 flowers (subsamples) per plant. Fruit were harvested and female fertility assessed as described previously.

Data from male and female fertility studies were analyzed using analysis of variance (PROC GLM, SAS Version 9.1.3; SAS Institute Inc., Cary, NC) and means compared using Fisher's protected least significant difference at $\alpha=0.05$.

\section{Results and Discussion}

Diploid plants had a mean 2C DNA content of $1.09 \pm 0.01$ (SEM) pg compared with a mean of $1.64 \pm 0.01$ (SEM) pg for triploids. The genome sizes were significantly different $(P<0.01)$ and consistent with their respective ploidy levels.

Male fertility. In the greenhouse study, ploidy level had a significant effect on pollen staining $(\mathrm{F}$ value $=5.76, P<0.0001)$ and germination $(\mathrm{F}$ value $=103.9, P<0.0001)$. Pollen from triploid plants had $29 \%$ to $60 \%$ staining compared with $83 \%$ staining for pollen from diploid plants (Table 1). Pollen germination for triploid plants was $0 \%$ to $23 \%$ compared with $63 \%$ pollen germination for diploid plants.

In the field study, ploidy level had a significant effect on pollen germination $(\mathrm{F}$ value $=804.5, P<0.0001)$ but not on pollen staining. Diploid plants had $76 \%$ pollen germination compared with $0 \%$ to $6 \%$ pollen germination for triploid clones (Table 2).

Because acetocarmine stains DNA and cytoplasm (Adeleke et al., 2002; Belling, 1921, 1926), these results indicate that the triploid plants produced some pollen grains with DNA and cytoplasm, but they may not necessarily be functional. Pollen staining often results in an overestimation of pollen viability (Olsen et al., 2006). Pollen germination was typically much lower than pollen staining, particularly for the triploids (Tables 1 and 2). Even so, the capacity for pollen to germinate does not ensure that it can complete fertilization and produce a functional embryo.

Female fertility. In the greenhouse study, crosses among diploids resulted in $97.7 \%$ fruit

Table 1. Pollen staining and germination rates of greenhouse-grown diploid $(2 x)$ control and triploid ( $3 x)$ clones of Hypericum androsaemum.

\begin{tabular}{lcc}
\hline Taxa & Pollen staining $(\%)$ & Pollen germination $^{z}(\%)$ \\
\hline Control $(2 x)$ & $83.1 \mathrm{a}$ & $62.5 \mathrm{a}$ \\
H2006-018-011 & $59.7 \mathrm{~b}$ & $12.9 \mathrm{bc}$ \\
H2006-018-003 & $57.3 \mathrm{bc}$ & $3.4 \mathrm{c}$ \\
H2006-018-010 & $54.2 \mathrm{bc}$ & $0.4 \mathrm{c}$ \\
H2006-018-012 & $53.8 \mathrm{bc}$ & $2.5 \mathrm{c}$ \\
H2006-018-005 & $48.0 \mathrm{bcd}$ & $1.5 \mathrm{c}$ \\
H2006-069 & $46.0 \mathrm{bcd}$ & $8.8 \mathrm{bc}$ \\
H2006-018-006 & $45.5 \mathrm{bcd}$ & $22.8 \mathrm{~b}$ \\
H2006-018-004 & $38.4 \mathrm{bcd}$ & $3.8 \mathrm{c}$ \\
H2006-019-005 & $37.1 \mathrm{~cd}$ & $0.0 \mathrm{c}$ \\
H2006-019-006 & $28.6 \mathrm{~d}$ & $1.8 \mathrm{c}$ \\
\hline
\end{tabular}

${ }^{\mathrm{z}}$ Means, $\mathrm{n}=5$, followed by the same letter within a column are not significantly different based on Fisher's protected least significant difference at $\alpha=0.05$. set with a mean of 340 seeds per fruit and a germination percentage of $76.4 \%$ (Table 3 ). This resulted in an average of 260 seedlings generated per flower. Triploid plants produced fruit and only three triploid clones produced less fruit than the diploid controls. However, all of the triploids produced fewer seeds than the diploid controls. Furthermore, the seeds produced by the triploids were not viable and failed to germinate in all but one of the triploids (H2006-069), which had a germination rate of $9.5 \%$, and those seedlings failed to grow beyond $1.5 \mathrm{~cm}$ in height before dying. As a result of the production of non-viable seeds, all but one of the triploid clones produced 0 seedlings per flower.

In the field study, natural pollination of diploid taxa resulted in $94.4 \%$ fruit set with an average of 132 seeds per fruit and a germination percentage of $66.4 \%$ (Table 4 ). As a result, an average of 100 seedlings was produced per flower. Triploid clones had varying levels of fruit set, but fruit had significantly fewer seeds per fruit and none of those seeds germinated resulting in an average of 0 seedlings per flower for all of the triploids.

The greenhouse and field studies demonstrated that under a range of environmental conditions, and with either controlled or natural pollination, triploid $H$. androsaemum had varying levels of fruit set, but these fruit had either nonviable seeds or seeds that produced abnormal or terminal seedlings. Nine of the 10 triploid cultivars had undetectable levels of female fertility in either study. These data were based on $\approx 25$ flowers from each plant with five replicates of nine taxa equaling 1125 flowers for the field study and five flowers from each plant with five replicates of nine taxa equaling 225 flowers for the greenhouse study. Based on a potential of 100 seedlings per flower for the control plants in the field and a potential 260 seedlings per flower for the control greenhouse plants, this represents $100 \%$ failure of $\approx 171,000$ potential fertilization events for the nine triploid clones. Triploids that reproduce through sexual pathways with normally reduced gametes are typically highly infertile owing to uneven segregation during meiosis (Sybenga, 1996) leading to abortive gamete or embryo development. This appears to be the case with triploid $H$. androsaemum. Like many triploid plants, triploid interspecific hybrids such as 
Table 2. Pollen staining and germination rates of field-grown diploid $(2 x)$ control and triploid $(3 x)$ clones of Hypericum androsaemum.

\begin{tabular}{lcc}
\hline Taxa & Pollen staining $^{\mathrm{z}}(\%)$ & Pollen germination $^{\mathrm{z}}(\%)$ \\
\hline Control & $64.8 \mathrm{a}$ & $75.9 \mathrm{a}$ \\
H2006-018-010 & $64.9 \mathrm{a}$ & $1.6 \mathrm{~b}$ \\
H2006-019-006 & $52.4 \mathrm{ab}$ & $0.7 \mathrm{~b}$ \\
H2006-018-011 & $51.3 \mathrm{ab}$ & $0.5 \mathrm{~b}$ \\
H2006-018-006 & $46.0 \mathrm{ab}$ & $1.3 \mathrm{~b}$ \\
H2006-018-003 & $39.7 \mathrm{ab}$ & $2.3 \mathrm{~b}$ \\
H2006-019-005 & $37.3 \mathrm{ab}$ & $0.4 \mathrm{~b}$ \\
H2006-018-012 & $35.4 \mathrm{ab}$ & $2.8 \mathrm{~b}$ \\
H2006-018-005 & $33.0 \mathrm{ab}$ & $1.0 \mathrm{~b}$ \\
H2006-069 & $30.3 \mathrm{ab}$ & $0.8 \mathrm{~b}$ \\
H2006-018-004 & $17.6 \mathrm{~b}$ & $5.5 \mathrm{~b}$ \\
\hline
\end{tabular}

${ }^{\mathrm{z}}$ Means, $\mathrm{n}=5$, followed by the same letter within a column are not significantly different based on Fisher's protected least significant difference at $\alpha=0.05$.

Table 3. Female fertility as a function of ploidy level in controlled pollination of greenhouse-grown Hypericum androsaemum.

\begin{tabular}{|c|c|c|c|c|}
\hline Taxa & $\begin{array}{c}\text { Fruit set }{ }^{\mathrm{z}} \\
(\%)\end{array}$ & $\begin{array}{l}\text { Seeds per } \\
\text { fruit }^{z}\end{array}$ & $\begin{array}{c}\text { Seed germination } \\
(\%)\end{array}$ & $\begin{array}{l}\text { Seedlings } \\
\text { per flower }\end{array}$ \\
\hline$\overline{\text { Control }}$ & $97.7 \mathrm{a}$ & $340 \mathrm{a}$ & $76 \mathrm{a}$ & $260 \mathrm{a}$ \\
\hline H2006-019-005 & $77.4 \mathrm{ab}$ & $29 \mathrm{~b}$ & $0 \mathrm{c}$ & $0 \mathrm{~b}$ \\
\hline H2006-018-003 & $72.2 \mathrm{ab}$ & $39 \mathrm{~b}$ & $0 \mathrm{c}$ & $0 \mathrm{~b}$ \\
\hline H2006-018-011 & $64.6 \mathrm{ab}$ & $15 \mathrm{~b}$ & $0 \mathrm{c}$ & $0 \mathrm{~b}$ \\
\hline H2006-069 & $64.1 \mathrm{ab}$ & $45 \mathrm{~b}$ & $9.5 \mathrm{~b}$ & $2 \mathrm{~b}$ \\
\hline H2006-018-006 & $60.0 \mathrm{ab}$ & $2 \mathrm{~b}$ & $0 \mathrm{c}$ & $0 \mathrm{~b}$ \\
\hline H2006-018-010 & $59.2 \mathrm{ab}$ & $16 \mathrm{~b}$ & $0 \mathrm{c}$ & $0 \mathrm{~b}$ \\
\hline H2006-018-005 & $56.4 \mathrm{ab}$ & $6 \mathrm{~b}$ & $0 \mathrm{c}$ & $0 \mathrm{~b}$ \\
\hline H2006-018-004 & $41.6 \mathrm{~b}$ & $1 \mathrm{~b}$ & $0 \mathrm{c}$ & $0 \mathrm{~b}$ \\
\hline H2006-018-012 & $41.6 \mathrm{~b}$ & $24 \mathrm{~b}$ & $0 \mathrm{c}$ & $0 \mathrm{~b}$ \\
\hline H2006-019-006 & $37.8 \mathrm{~b}$ & $20 \mathrm{~b}$ & $0 \mathrm{c}$ & $0 \mathrm{~b}$ \\
\hline
\end{tabular}

${ }^{\mathrm{z}}$ Means, $\mathrm{n}=5$, followed by the same letter within a column are not significantly different based on Fisher's protected least significant difference at $\alpha=0.05$.

Table 4. Female fertility as a function of ploidy level in natural pollination of field-grown Hypericum androsaemum.

\begin{tabular}{lcccc}
\hline Taxa & $\begin{array}{c}\text { Fruit set } \\
(\%)\end{array}$ & $\begin{array}{c}\text { Seeds } \\
\text { per fruit }\end{array}$ & $\begin{array}{c}\text { Seed germination } \\
(\%)\end{array}$ & $\begin{array}{c}\text { Seedlings }^{z} \\
\text { per flower }^{z}\end{array}$ \\
\hline Control & $94.4 \mathrm{a}$ & $132 \mathrm{a}$ & $66 \mathrm{a}$ & $100 \mathrm{a}$ \\
H2006-018-011 & $64.9 \mathrm{ab}$ & $6 \mathrm{~b}$ & $0 \mathrm{~b}$ & $0 \mathrm{~b}$ \\
H2006-018-005 & $57.8 \mathrm{bc}$ & $0 \mathrm{~b}$ & $0 \mathrm{~b}$ & $0 \mathrm{~b}$ \\
H2006-018-003 & $43.8 \mathrm{bcd}$ & $4 \mathrm{~b}$ & $0 \mathrm{~b}$ & $0 \mathrm{~b}$ \\
H2006-019-006 & $38.5 \mathrm{bcd}$ & $3 \mathrm{~b}$ & $0 \mathrm{~b}$ & $0 \mathrm{~b}$ \\
H2006-019-005 & $24.1 \mathrm{cde}$ & $7 \mathrm{~b}$ & $0 \mathrm{~b}$ & $0 \mathrm{~b}$ \\
H2006-018-010 & $13.6 \mathrm{de}$ & $3 \mathrm{~b}$ & $0 \mathrm{~b}$ & $0 \mathrm{~b}$ \\
H2006-018-012 & $10.4 \mathrm{de}$ & $2 \mathrm{~b}$ & $0 \mathrm{~b}$ & $0 \mathrm{~b}$ \\
H2006-018-004 & $9.6 \mathrm{de}$ & $0 \mathrm{~b}$ & $0 \mathrm{~b}$ & $0 \mathrm{~b}$ \\
H2006-069 & $1.8 \mathrm{e}$ & $7 \mathrm{~b}$ & $0 \mathrm{~b}$ & $0 \mathrm{~b}$ \\
H2006-018-006 & $1.3 \mathrm{e}$ & $0 \mathrm{~b}$ & - & $0 \mathrm{~b}$ \\
\hline
\end{tabular}

${ }^{2}$ Means, $\mathrm{n}=5$, followed by the same letter within a column are not significantly different based on Fisher's protected least significant difference at $\alpha=0.05$.

with Vaccinium spp L. have shown a high degree of sterility as measured by pollen viability, percent fruit set, number of seeds per fruit, and percent seed germination (Chavez and Lyrene, 2009; Dweikat and Lyrene, 1988).

This study evaluated fertility of triploid clones of $H$. androsaemum that were developed and selected for desirable foliage colors, foliar variegations, and non-invasiveness. Greatly reduced male fertility was found in both controlled and uncontrolled conditions and there was no detectable female fertility
Bailey, L.H. 1949. Manual of cultivated plants. Macmillian Pub. Co, New York, NY.

Belling, J. 1921. On counting chromosomes in pollen-mother cells. Am. Nat. 55:573-574.

Belling, J. 1926. The iron-acetocarmine method of fixing and staining chromosomes. Biol. Bull. 50:160-162.

Brewbaker, J.L. and B.H. Kwack. 1963. The essential role of calcium ion in pollen germination and pollen tube growth. Amer. J. Bot. 50:859-865.

Chavez, D.J. and P.M. Lyrene. 2009. Interspecific crosses and backcrosses between diploid $\mathrm{Vac}$ cinium darrowii and tetraploid southern highbush blueberry. J. Amer. Soc. Hort. Sci. 134: 273-280.

Dias, A. 2003. The potential of in vitro cultures of Hypericum perforatum and of Hypericum androsaemum to produce interesting pharmaceutical compounds, p. 135-154. In: Ernst, E. (ed.). Hypericum. Taylor and Francis Group, New York, NY.

Doležel, J., J. Greilhuber, S. Lucretti, A. Meister, M.A. Lysa'k, L. Nardi, and R. Obermayer. 1998. Plant genome size estimation by flow cytometry: Inter-laboratory comparison. Ann. Bot. (Lond.) 82:17-26.

Dweikat, I.M. and P.M. Lyrene. 1988. Production and viability of unreduced gametes in triploid interspecific blueberry hybrids. Theor. Appl. Genet. 76:555-559.

Greihuber, J., E.M. Temsch, and J.M. Loureiro. 2007. Nuclear DNA content measurement, $p$. 67-101. In: Doležel, J., J. Greilhuber, and J. Suda (eds.). Flow cytometry with plant cells: Analysis of genes, chromosomes and genomes. Wiley, Weinheim, Germany.

Huxley, A., M. Griffiths, and M. Levy. 1992. The New Royal Horticultural Society dictionary of gardening. Macmillan, London, UK.

Marquard, R.D. 1992. Pollen tube growth in Carya and temporal influence of pollen deposition on fertilization success in pecan. J. Amer. Soc. Hort. Sci. 117:328-331.

Matzk, R., K. Hammer, and I. Schubert. 2003. Coevolution of apomixis and genome size within the genus Hypericum. Sex. Plant Reprod. 16:51-58.

Olsen, R.T., T.G. Ranney, and D.J. Werner. 2006. Fertility and inheritance of variegated and purple foliage across a polyploid series in Hypericum androsaemum L. J. Amer. Soc. Hort. Sci. 131:725-730.

Palmer, I.E., T.G. Ranney, N.P. Lynch, and R.E. Bir. 2009. Crossability, cytogenetics, and reproductive pathways in Rudbeckia subgenus Rudbeckia. HortScience 44:44-48.

Robson, N.K.B. 1985. Studies in the genus Hypericum L. (Guttiferae). 3. Campylosporus to 6a. Umbraculoides. Bul. Brit. Museum (Natural History) Bot. Ser. 12:163-325.

Robson, N.K.B. and P. Adams. 1968. Chromosome numbers in Hypericum and related genera. Brittonia 20:95-106.

Sybenga, J. 1996. Chromosome pairing affinity and quadrivalent formation in polyploids: Do segmental allopolyploids exist? Genome 39:11761184.

Adeleke, M.T.V., M. Pillay, and B.E. Okoli. 2002. An improved method for examining meiotic chromosomes in Musa L. HortScience 37:959961.
Weber, E. 2003. Invasive plant species of the world: A reference guide to environmental weeds. CABI, Cambridge, MA. 